EL HECHO DE QUE 節について

福黨教隆

I. 序

イスパニア語の直説法と接结法の連いは、"realidad / no realidad" の 对立として説明されることが多い。1)次のような名部修笁節における叙法の 使用制限は、その好例である。

(1) a. la seguridad

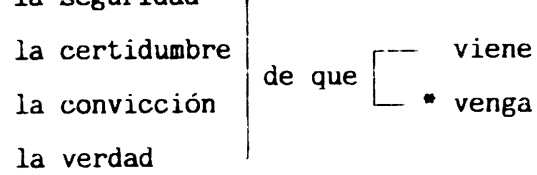

b. la necesidad

$\begin{aligned} & \text { la posibilidad } \\ & \text { la verguienza } \\ & \text { la duda }\end{aligned} \mid$ de que $\left.\right|_{-. .}$venga

ところが周知の通り el hecho de que に節では、先行名詞が明 白な「事実」を表わすにも保わらず、従趿詞が接続法をとることがあり、 先述の锐明と矛盾する。次例を参照。

(2) a. El hecho de que la Iglesia Católica adoptara el latín como lengua litúrgica, ha asegurado la pervivencia de este idioma hasta nuestros días. (F. Lázaro Carreter, Lengua Española)

b. Ojalá, digo, al Perú de Vargas Llosa y a la Checoslovaquia de Havel les vaya bien con su novelista y con su dramaturgo. Pero el hecho de que hasta ahora sus respectivos of $i-$ cios hayan sido esos no permite inferir nada, ni bueno ni 
malo, sobre su rendimiento en la política profesional. (Cambi6, 26-II-1990)

本䅧の目的は、このような節における叙法形態がいかにして決定されるか を考察することにおる。

II. 従来の研究

El hecho de que 節に関しては、これまでに多くの研究がある。概して生

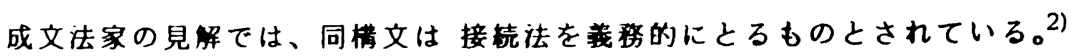
またFente 他（1972）のように、「直説法も接梳法もとり得るか、その意 味的対立は弱まり中和されている」と見る立場もある。

一方では、「el hecho de que の後には雨叙法とも現われ、その使い分け によって意味的差異が生じる」と説く研究者も多い。例えば Fernández Ramírez (1986) は、「值説法は、節の内容を主張として前面に押し出す時に 用い、接続法は、既に了解されている事項や、伝達济みの情赫を表わす時に 用いる」と述べている。

これと関連する見解は、Togeby（1953）や出口（1982）の著作にも見られ る。即ち el hecho de que 節中の接纾法について、前者は「節の内容が主 たる情報ではなく、他の情報の出発点に過ぎいことを示す」と説き、捘者 は「P（命影／筆者注）を他の大きなP $\mathrm{P}$ ので、それについて述べる題目と

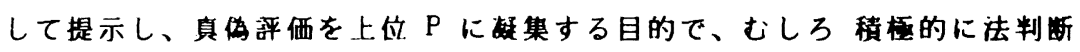
を差し栐えるためではないか」と解躯しているのである。更にTerrell 他 （1974）は「［一主張］、［+前提］」という、ごく端的な表現で、同梾の 観察を整理している。

El hecho de que 節中に両叙法の意味的対立を諗める立場では他に、「直 説法は事実や皘的主張を示し、接结法は仮定、説明、非現実的前提を表わ す」とするWoehr (1975) や、「直説法は言明や知臹の表現に、接轹法は影 暂や価值判断の表現に用いる」とするButt 他（1988）などの言及がある。

同節が文中に占める位置に着目した研究も多い。Blücher (1979) は rel hecho de que 節がその他の箅に先行する埸合も、後行する坦合も、两叙法 か現われ得る」と述べているが、「他の節に先行する時は接娔法が多く、後 
行する時は直説法が多い」と指摘する学者もいる。例えば先述の Fernández Ramirez, Woehr, Butt 他や、Guitart (1982) が、それに該当する。

以上、el hecho de que 節に関する従来の研究を概観した結果、相反する 見解が提出されている䦗題が幾つか在することが明らかになった。第 に、同節中には、接続法しか現われ得ないのか、それとも淔説法も許容され るのだろうか。第 2 に、仮に両叙法が胃われ得るとして、その使い分けはど のような意味的差異をもたらすのだろうか。第 3 に、同第が文中に占める位 畳と叙法とは、どのような相関関係にあるのだろうか。

以下では、これらの疑問点を検討すべく、文例収集とインフォーマント調 查によって得られたテータの分析を行なう。そして議論の能率化を四るた め、作莱仮説をたてて、テータへの適用可能性を見ていくことにする。差し 当たり Fernández Ramirez 説、即ち「el hecho de que 節中の直説法は、 情卦を主張陳述し、接统法は、或る陳述のための前提を表わす」という考え 方か、賛同者が多いようなので、これを作業伇説としたい。

\section{III. 調查}

\section{1 文例収集}

資料体として次の 15 の文献を選ひ、それそれ右端に記すような数の文例 を得た。

直说法接続法

(3) a. A.M. Matute, Los Abel, 1948.

$0 \quad 1$

b. A. Casona, La barca sin pescador, 1945.

$0 \quad 0$

c. J. Calvo Sotelo, La muralla, 1954.

$0 \quad 0$

d. A. Sastre, La mordaza, 1954.

e. M. Mihura, Maribel y la extraña familia, 1959. 000

f. A. Paso, La corbata, $1963 . \quad 000$

g. A. Buero Vallejo, Llegada de los Dioses, 1971. 000

h. J. Salom, La noche de los cien pájaros, 1972. 000

i. J. Rulfo, El llano en llamas, 1953.

j. G. García Márquez, El coronel no tiene quien $0 \quad 0$ 
le escriba, 1961.

k. J. Edwards, Las máscaras, 1967.01

1. Y. Mishima, El marino que perdió la Gracia $\quad 1 \quad 1$ del mar, J.Z. Goicoechea 訳, 1983.

m. M. Esgueva 他, El habla de la ciudad de $\quad 0 \quad 0$ Madrid, 1981, CSIC. (調查 I, II, V, VI, XI, XII, XV, XVI)

n. M.A. de Pineda, Encuestas del habla urbana 11 de Sevilla, 1983, Univ. de Sevilla. （調查 ClVl, ClV2, ClHl, C2Vl, C2Hl, C3V1, C3Hl, $\mathrm{C} 3 \mathrm{H} 2$ )

o. Cambio 16誌, 550 683号 (1982.6.14 1984. 12.31）の投書䍏 "Entre nosotros"。

(3.a) は現代イスパニアの小説、(3.b〜h) はイスパニアの战曲、（3.i〜 k)はイスパノアメリカの小説、(3.1) は三島由紀夫「午後の史航」のイス パニア語訳、(3.m〜n) は口語筫料、(3.0) はイスパニアの䢙刊諘の一部で ある。一見して分かるように el hecho de que 節の使用頛度はそう高いも のではないが、文学作品や日常会念と比べれば、詥説的な文章に多く見られ ると言えよう。直説法の文例が 11、接䊦法の文例が 16 得られたので、第 2 節であげた第1の疑問点、即ち、当該の表現にはいずれか一方の叙法しか 現われないのかという点については、否という解答が 与えられたことにな る。

11例の直説法の文のうち、幾つかを見てみよう。

(4) Por último, y aunque el gesto de la libreta dejaba claro que en Ryuji no había motivación espúrea alguna, quedaba el hecho de que la baja espectacular de los embarques habia dado lugar a una quiebra de los valores marítimos, y que por otra parte era evidente que Ryuji tenía intención de acabar con su carre- 
ra de marino. Fusako debía cuidarse bien de no comprometerse por el mero hecho de ser viuda. ((3.1) Mishima)

（原文：第五に、眝金涱の件をとってみても、打算的な男でないこと はわかるか、昨年からのひどい海通不况で、船会社の铢も軒並に下が っている折りでもあり、彼のほうでも、ここらで然員稼業の起を㧥い たい気のあったことは確かだから、局子も未亡人だからと云っていた ずらに告届にならず、あくまで対等の態度を持して、相手になめられ ないように気をつけること。)

これは「房子」という登場人物が、再婚を考えるに当たって、知人から受 けた忠告の1つである。イスパニア語の第1の文は、まず謡步をしておいて から、相手に訴えたい事項を el hecho de que 以下で伝えている。即ち、 後半が中心的情報を担っており、かっそこに淔説法が使われているので、(4) は作業仮説に商合した例であると言えよう。

(5) Se tiene que subrayar también el hecho de que, con la masa tan enorme de estudiantes extranjeros, el nivel de enseñanza no está en concordancia con su fama. ((3.0) Cambi6, 16-VII-1982)

この文は「その教育機関の水準は評判はどでもない」ことを「強調すべき だ」という内容であるから、el hecho de que 節が主たる陳述部分だと考え て差し支えなかろう。

(6) Quisiera llamar la atención sobre el hecho de que en Finlandia la libertad de prensa está garantizada en la legislación. ( (3.

o) Cambi6, 6-XII-1982)

「フィンランドでは出版の自由が法律で保証されていることに注意を喚起 したい」という、この例も、作业仮説に合致していることが、その主節の意 味内容から明らかである。

(7) No creo que haga el articulo de Maruja Torres mucha propaganda a unas fiestas y una provincia como Navarra informando que las personas que asistimos a esas fiestas sin igual somos morralla, y menos mal que los navarros saben catalogar el hecho de que, como en todas las reuniones de multitudes, hay personas 
de toda clase. ((3.0) Cambi6, 20-VIII-1984)

䓢刊誌の記事を批判する投青である。具体的な䦓題を指摘したあと、「批 の中には色々な人がいる。幸いなことに我々ナバラ人は、そのことをよくわ きまえている。」と結ぶのだが、その文末部分に植説法の el hecho de que 節が用いられている。ここが芜み手に注目してほしい箇所であると見て良か ろう。

このように、11例中8例は、先に設けた怍業仮説に照らして矛盾がな が、2例は、やや鱼合性に雉問があり、次にあげる1例は明らかに不整合で ある。

(8) ¿Acaso tiene algo que ver el hecho de que Greiber es judío con la sospecha de que estaba ligado con los montoneros argentinos? ((3.0) Cambi6, 20-XII-1982)

つまり (8) においては、el hecho de que 節の示す「グレイバーがユダヤ 人だということ」を筒まえて、「それが、彼とアルゼンチンの過旅とのつ ながりについての潇知と、何の関係があるというのか」という生たる陳述が 行なわれている。作業仮説に従えば、このように前提となる事実を表わす場 合には接娃法をとる方がふさわしいはずだが、実際には淔説法になっている 訳である。

では次に、接结法の文例の検討に移ろう。

(9) "iQue se casen, pues!," dijo Domitila; "si la niña lo quiere.. .." El solo hecho de que Domitila aceptara esta idea como algo no imposible, de que permitiera enunciarla, lo que significaba que no era absurda en sí misma, al menos para Domitila, y por lo tanto, que no era totalmente absurda, me produjo un malestar físico. ((3.k) Edwards)

「「好きなら結嫫すれはいいじゃない」とドミティラは吉った。彼女がそ う考え、そうロにしたということだけで、他人の目から見ても二人の結婚が まんざらナンセンスではなさそうだということが分かる。私は贯䝍になっ た。というような趣旨の一節である。この例では、el hecho de que 以下 の内容が事実であることが、直前の文によって明らかである。従ってく接礼 
法は非胃実を表わす」という考え方にとっては反例となるが、本稿の作業仮 説のように、「ある事項を睍害と認めつつ、それを前提とすること」と「あ る事項を現実であるとして主張すること」を区别する立場をとれば、こく自 然な用例である。即ち el hecho de que 節の表わす事実を前提とし、それ に対して「私」がどのような感情を抱いたかが、第 2 の文の伝える主たる情 報だと思われるからである。

(a0 Noboru abrió un libro de texto y hojeó unas cuantas páginas, pero no podía concentrarse. Le molestaba demasiado el hecho irrefutable de que Ryuji y su madre no estuvieran en casa. ((3.1) Mishima)

（原文：いくら参考書をひっくり返しても、心は少しもそこに止まら なかった。母と童二が今夜は整実にここにいないということが、却っ て彼を悩ましくさせていた。)

El hecho de que 節の内容が 事実であることは、文脈だけでなく、hecho に冠せられた irrefutable という形容詞によっても明賍である。しかし (00) の第 2 の文は、その事実を伝達するのが本義ではなく、そのために主人公が 悩んでいるということを、表明しようとしていると考えられる。従ってこれ も「前提となる事項は接做法で表わす」という、本稿の作業仮説と合致する 例の 1 つである。

av El hecho de que el tabaco o el alcohol estén legalizados no da derecho a potenciar el consumo y legalización de otras drogas. ((3.0) Cambi6, 7-III-1983)

この文では、煌草やアルコールが法的に認められているという常䧕的事実 を路まえて、「だからと言って麻菜まで合法化して良いということにはなら ないよというま張が行なわれている。これまた、接続法を非胃実の法とみな す見地では捉え菓く、作業仮説にとってはこく自然な事的である。

ad Dado el parecido con nuestro nombre comercial Ceys, que corresponde a Comercial de Exclusivas y Suministros, de la que soy gerente, y el hecho de que la secta Ceis radique también en Barcelona, hemos tenido numerosas situaciones en las que se 
han creado confusiones por parte de algunos de nuestros clientes en los ramos de ferretería, droguería, papelería y público en general. ((3.0) Cambi6, 8-X-1984)

rCeys と Ceis は、名前が做ている上に、どちらもバルセロナを根地地に しているので、度々取り䢖えられた」という文である。el hecho de que 節 は、dadoという週去分詞に後続しており、主節の陳述のための前提を表わ していることが、形式的に明示されている。

a3 El mero hecho de que en España esté extendiéndose la desertización es una buena muestra de la inoperancia de este Instituto. ((3.0) Cambi6, 10-XII-1984)

「础淡化の進行一つを甽にとっても、問题の施設がいかに無能かがよく分 かる」という詥旨である。El hecho de que 節は轺論の前提となる命題を司 っていると言える。同䈨に meroという修質語が付いているのは、第の内容 自体を主張しょうとしているのではないことの証左だと見ることもできよ jo3)

結局、16例中15例までは、作業仮説によって無理なく説明できる。仮説 が適用しにくいのは、次の1例のみである。

04 Lo demuestra también el hecho de que hubiera aceptado previamente ante el ministro del Interior y que incluso hubiese hecho manifestaciones a la prensa navarra en condición prácticamente de nuevo delegado del Gobierno en dicha comunidad. ( 3.

o) Cambi6, 17-I-1983)

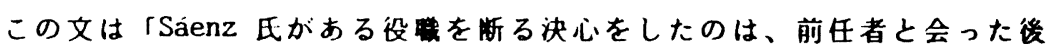
のことだ。」という文に続くもので、「その証拋に、同氏はその瞳を受諾す る旨を内稀大臣に表明したし、記者会見にもその努勢で絽んだ」といった内 容である。El hecho de que 節は重要な情報を担っていると考えられるか ら、作莱仮説に基つけけは、直説法が現われても良さそうであるが、従属動詞 は接䌼法になっている。

以上の钼察をまとめると、先に設けた作業仮説は、いずれの叙法において も、少数の非道合例があるものの、収集文例の大多数に道合する、というこ 
とになる。

一方、第 2 章で見た他の見地は、これほどの包括力を持たない。「仮定や 非現実的前提は接纾法によって表わされる」というWoehr 説には、ただち に反例があげられるし、Butt他の記述は、更に一般化すれば、本稿の作莱 仮説に至ると思われる。

なお el hecho de que 節と他の節との顛序については、次のような結果 が得られた。直説法の場合、他の第に先行するのは1例のみて、、残りの 10 测は後行する。接䌼法の婸合、10例が他の節に先行し、6 例が後行する。即 ち、狳法と語盾とは無関係ではないと言えよう。直説法の用例の大半が後行 節で、接䓋法の用例の週半数が先行節であるということは、先の作業仮説と 合致する。前提をまず述へたあと、主たる陳述を行なうという顆序を無姞の ものと考えると、el hecho de que 第が文の前半に位置するとき接続法をと り、後半に疋かれるとき直説法をとる㑯向がおのずと生じるはずだからであ る。

\section{2 インフォーマント調査}

収集文阿における叙法摆択が、どの程度一般的なものかを知るため、イン フォーマント調查を行なった。7人の母語話者4)に、収集した27文例全て と、そのうち3つに手を加えた文とを提示し、各々について苗説法と接続 法のどちらを用いるのが部当と思うかを問うものである。回答者の内訳は、 イスパニア人男性 4 名、グアテマラ人男性、ペルー人女性、アルセンチン人 男性各 1 名である。次にその成果を記す。(15.a〜j) は、原文では直説法が 用いられていた事例、(15.k〜W) は、同じく接谎法が用いられていた事例、 (15.ch'，i'，W') は、それに手を加えた文である。

015

\begin{tabular}{|c|c|c|c|c|c|c|c|c|c|c|}
\hline & $\begin{array}{c}\text { 本䅻の } \\
\text { 番号 }\end{array}$ & $\begin{array}{l}\text { 仮説の } \\
\text { 透合牪. }\end{array}$ & $E$ & $E$ & E & $E$ & G & $P$ & $A$ & $\%$ \\
\hline a. & (4) & 0 & $\mathrm{i}-$ & $\mathrm{i}-$ & $\mathrm{i}$ - & $-s$ & i s & $\mathrm{i} s$ & $\mathrm{i}-$ & 77 \\
\hline b. & & $\Delta$ & $-s$ & i s & i $s$ & $-\mathbf{s}$ & i s & $\mathrm{i}(\mathrm{s})$ & i's & 51 \\
\hline
\end{tabular}




\begin{tabular}{|c|c|c|c|c|c|c|c|c|c|c|c|}
\hline c. & & 0 & (i) $\mathrm{s}$ & $\mathrm{i}-$ & $\mathrm{i}-$ & $\mathrm{i}-$ & & $\mathbf{s}$ & i s & $\mathbf{i}-$ & 74 \\
\hline ch. & (5) & 0 & $\mathrm{i}(\mathrm{s})$ & $\mathrm{i}-$ & $\mathrm{i}-$ & $\mathrm{i}-$ & $\mathbf{i}$ & $s^{\prime}$ & $\mathrm{i}-$ & i - & 90 \\
\hline d. & (6) & 0 & i (s) & $\mathrm{i}-$ & $\mathrm{i}-$ & $\mathrm{i}-$ & & s & $\mathrm{i}-$ & $\mathbf{i}-$ & 87 \\
\hline e. & (8) & $x$ & $-s$ & $i^{\prime} s$ & $\mathrm{i}-$ & $-s$ & & $\mathbf{s}$ & $-s$ & (i) $\mathrm{s}$ & 45 \\
\hline f. & & $\Delta$ & $-s$ & $\mathrm{i}-$ & $-s$ & $-s$ & & $\mathbf{s}$ & (i) $\mathrm{s}$ & $-s$ & 42 \\
\hline g. & & 0 & $\mathrm{i}-$ & $\mathrm{i}-$ & $-s$ & $-s$ & & $\mathrm{~s}$ & $-s$ & $\mathrm{i}-$ & 60 \\
\hline h. & & 0 & $\mathrm{i} s$ & $\mathbf{i}-$ & $\mathrm{i}-$ & $\mathrm{i}-$ & $\mathrm{i}$ & $\mathbf{s}$ & $\mathrm{i}-$ & $\mathrm{i}-$ & 82 \\
\hline i. & (7) & $O$ & $\mathrm{i} s$ & $\mathrm{i}-$ & $i-$ & $\mathrm{i}-$ & & $\mathrm{s}$ & i s & i - & 75 \\
\hline j. & & 0 & $\mathrm{i} s$ & $\mathrm{i}(\mathrm{s})$ & $\mathrm{i}-$ & $\mathrm{i}-$ & $\mathfrak{i}$ & s & $i(s)$ & $\mathrm{i} \mathrm{s}^{\prime}$ & 73 \\
\hline k. & & 0 & (i) $\mathrm{s}$ & (i) $\mathrm{s}$ & $-s$ & $-s$ & & $\mathrm{~s}$ & $i(s)$ & (i) $\mathrm{s}$ & 26 \\
\hline 1. & & 0 & $-s$ & i's & $-s$ & $-s$ & $\mathrm{i}$ & s & $\mathrm{i} s$ & $-\mathbf{s}$ & 23 \\
\hline 11. & (9) & 0 & $-s$ & i's & $-s$ & $-s$ & & $\mathrm{~s}$ & (i) $\mathrm{s}$ & $\mathrm{i}(\mathrm{s})$ & 26 \\
\hline m. & (10) & 0 & $-s$ & i $\mathbf{s}$ & $-s$ & $-s$ & & s & i s & $\mathrm{i}(\mathrm{s})$ & 32 \\
\hline $\mathrm{n}$. & & 0 & $-s$ & $\mathrm{i} s$ & $-s$ & -- & & s & -- & $-s$ & 22 \\
\hline$\tilde{\mathrm{n}}$. & & 0 & $-s$ & i's & $-s$ & $-s$ & & $\mathrm{~s}$ & $\mathrm{i} s$ & $-s$ & 21 \\
\hline 0. & & 0 & $-s$ & $\mathrm{i}-$ & $-s$ & $-s$ & $\mathrm{i}$ & s & $\mathrm{is}$ & $-s$ & 27 \\
\hline p. & (14) & $x$ & (i) $\mathrm{s}$ & $\mathrm{i} s$ & $-s$ & $-s$ & $\mathrm{i}$ & s & $\mathrm{i}-$ & $\mathrm{i}(\mathrm{s})$ & 37 \\
\hline q. & & 0 & $-s$ & $\mathrm{i}^{0} \mathrm{~S}$ & $-s$ & $-s$ & $\mathrm{i}$ & $s^{\prime}$ & $-s$ & $-s$ & 16 \\
\hline r. & (11) & 0 & $-s$ & i's & $-s$ & $-s$ & $\mathrm{i}$ & $s$ & $-s$ & i's & 21 \\
\hline $\mathrm{rr}$. & & 0 & $-s$ & $i^{\prime} s$ & $-s$ & $-s$ & & s & $-s$ & $-s$ & 10 \\
\hline s. & & 0 & $-s$ & $i^{*} s$ & $\mathrm{i}-$ & $-s$ & & $\mathrm{~s}$ & i s & $-s$ & 31 \\
\hline t. & & 0 & $-s$ & (i) $\mathrm{s}$ & $-s$ & $-s$ & & $\mathrm{~s}$ & $\mathrm{i} \mathbf{s}$ & i's & 25 \\
\hline u. & 00 & 0 & $-s$ & i $s^{\prime}$ & $-s$ & $-s$ & & $\mathrm{~s}$ & $\mathrm{i}-$ & $\mathrm{i}(\mathrm{s})$ & 36 \\
\hline v. & & 0 & $-s$ & (i) $\mathrm{s}$ & $-s$ & $-s$ & & s & $\mathrm{i} s$ & (i) $\mathrm{s}$ & 23 \\
\hline w. & 03 & 0 & $-s$ & i $s^{\prime}$ & $-\mathrm{s}$ & $-s$ & & $\mathrm{~s}$ & (i) $\mathrm{s}$ & $i^{\prime} s$ & 26 \\
\hline $\mathrm{ch}^{\prime}$ & 00 & & $-s$ & $i-$ & $\bar{i}-$ & $-s$ & & $\mathrm{~s}$ & (i) $s$ & $i-$ & 45 \\
\hline$i^{\prime}$ & (17) & & $-s$ & $\mathrm{i}-$ & $\mathfrak{i}-$ & $-s$ & - & s & $-s$ & $\mathrm{i}-$ & 43 \\
\hline w' & 018 & & $-s$ & $i s^{\prime}$ & $-s$ & $-s$ & - & s & (i) $\mathrm{s}$ & i $s^{\prime}$ & 27 \\
\hline
\end{tabular}


Q0 ¿Quién subraya el hecho de que el nivel de enseñanza no (está/ esté) en concordancia con śu fama? ((5) より)

(17) ¿Quiénes saben catalogar el hecho de que (hay / haya) personas de toda clase? ((7) より)

08 ¿De qué es una buena muestra el hecho de que en España \{está / esté\} extendiéndose la desertización? ((13)より)

表中、「仮説の合性」の項は、各収集文例が作業仮説と合致しているか

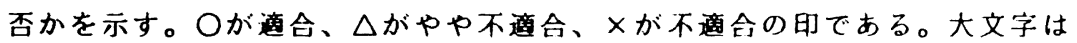
回答者の国籍を表わす。E: España、G: Guatemala、P: Perú、A：Argentina である。i、sは直説法、接统法の峈である。単にi、sと記してあるのは、 与えられた文脈でその形態が目然であることを示す。アポストロフィーが付 いているときは、その形態も使えるが、他方の形態が一層好ましいことを示 す。(i)、(s) のように括卯に包まれているのは、その形態の使用がやや不自 然であることを示す。ハイフンは、全く不目然であることを示す。5)

例えば(15.b) に関しては、イスパニア人 2 名は「接続法のみが適切であ る」と考え、他の 2 名のイスパニア人とグアテマラ人とは「直説法も接䊦法 も同等に目然である」と答え、ペルー人は「值説法が道切で接続法はやや奇 異だ」と感じ、アルゼンチン人は「両叙法とも可能だが、接続法の方がより 良い」と判断した訳である。

以上のような回答を点数に换算して、各文の直説法、接娃法の許突度の指 標を出してみた。表の右端の「\%」の項がそれである。i、sは 3 点、i”、s' は 2 点、(i)、(s) は1点、ハイフンは0点とし、命計する。原文における 法形態の選択には入念な内省が场いているものと考え、i、s の倍の6 点を 与える。

先の（15.b）を再び例にとると、淔説法の得点は $6+0+3+3+0+3$ $+3+2=20$ 、接䊦法の得点は $3+3+3+3+3+1+3=19$ である から、この文の直説法性は $20 \div(20+19)=51 \%$ 、接続法性はそれを 100

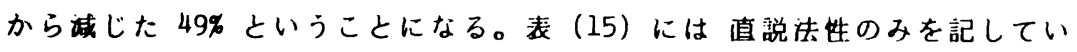
る。即ち、この数值が高ければ、当該の文に值説法が見われやすいことを示 し、低ければ、接续法が現われやすいことを示すのである。インフォーマン 
トの回答間には個人差が大きいが、こうして平均值を算出すると、全体の㑯 向が把握できる。

まず (15.a〜j)、つまり原文では直説法が用いられていた事例に着目しよ う。全般的に\%が高く、従って直説法を好む顿向にある。しかし中には％の あまり高くない文もある。「文例収集」の項で、作策仮説とやや不整合とな

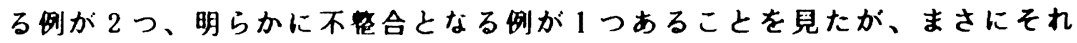
が、インフォーマント調査で低い直説法性しか得られない(15.b、e、f)に 他ならない。それゆえ、作業伇説の適用しづらい用例は、母語話者にとって も质抗のある文だということになり、本稿の仮説を支持する1つの根拋が得 られたと言えよう。

次に $(15 . \mathrm{k} \sim w)$ 、即ち元の文章には接姯法が使われていた事例を検討しよ う。いずれも\%の項は低い数值であり、イシフォーマント調查の回答者たち の判断が、原文の発話者の判断と近做することを物語っている。ただし作莱 仮説で説明し整い㫿一の例であった（15.p）は、他に比べて高い\%を示して いるので、ここでも仮説の妥当性が裹づけられる。

最後に、原文に手を加えてできた（15.ch'、i'、W'）に対する母語話者の 反応を見よう。これらは元の文を部分疑問文に改めたものである。部分是問 文では是問詞に話者の関心が集中し、その他の䇢所は、いわば背景化してし まうから、もし作業仮説が正しければ(15.ch'、i'、W') の el hecho de que 節では、接赎法が好まれるという予即が立つ。そして実際に、元になる 文 (15.ch、i) は各々 90\%、75\% という高い直説法性を示すのに対し、是問 文化すると、45\%、43\% と著しく数值が低下する。また元来、接耖法性の高 かった (15.W) は筑問文に改めても、26\% から27\%と、数值にほとんど变 動が見られない。仮説による予即と、調查轺果とが一致した訳である。

要するにインフォーマント調査の結果は、本稿の作業仮説と整合するもの である。文例収集の段階で散見された、仮説の道用が困熟な事㓠について も、一応の説明がえられたと言える。

\section{IV. 结哈}

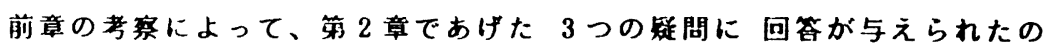


でこれをもって本稡の結論とする。第 1 に、el hecho de que 節中の叙社 は、いずれか一方に機械的に固定されているのでも、意味の対立を失ってい ろのでもない。直説法と接娃法は、同節に意味的な差異を生むと見て良い。

第 2 に、その意味的差異で特筆すべきは、「直説法は、その内容を主たる 情船として強く前面に呈示し、接桡法は、他の陳述を支える背暴部分を担当 する」点である。この连いに注目することによって、「接続法は非見実を表 わす」という見地では説明のつかない用例が、無理なく理解される。つまり 作業仮説に用いた Fernández Ramirez らの钼察は、基本的に妥当だと考え られる。

第 3 に、いま述べた叙法対立に伴って、el hecho de que 節が直説法をと るときは、他の節に後行することが多く、接結法をとるときは、先行しがち になることが指揞できる。

本稿を結ぶにあたって、「直説法は主張陳迹を表わし、接続法は背暴素材 を表わす」という考え方は、el hecho de que 節のみならす、他の構文の分 析にも有勃ではないかと思われることを、費き添えておく。

拄

* 本稿は、1989年12月3日、鹿児血経济大学にて開かれた日本イスパニヤ 学会第35回大会でのし頭発表に基づくものです。貫重な御教示を睗った先 生方に㫗く御礼申し上げます。なお收集例一覧やインフォーマントの回答 の詳練などについては拙稿（1989、集储中）を御参照下さい。

1) 例えは Real Academia Española (1973: 454) を参照。

2) Demonte (1977) など。

3）（10）や（13）のように形容詞が hecho を節する例は全部で 5 例あ り、いずれも接続法の文である。

4) 以下の各氏。José Fernández, Germán Arce, Manuel Brunet, José Varela (以上E), Bernal Herrera (G), Isabel Espino (P), Hilario Kopp (A)。(敏称略)

5）（15.n）については、両叙法ともハイフンとする回答が 2 名の人から得 
られた。これは、原文が(3.n) から採ったロ語発舕なので、文末が完 結していないことによる。

\section{引用文献}

Blücher, Kolbjørn (1979) "Les niveaux fonctionnels du subjonctif en espagnol, en français et en italien," Revue Romane 16.

Butt, John 他 (1988) A new reference grammar of modern Spanish, Edward Arnold, London.

出口厚実（1982）「スペイン語における叙法と法性」、大阪外国語大学学報 56.

Demonte, Violeta (1977) La subordinación sustantiva, Cátedra, Madrid.

Fente, Rafael 他 (1972) El subjuntivo, SGEL, Madrid.

Fernández Ramírez, Salvador (c. 1950) I. Bosque (1986) Gramática española 第 4 巻、Arco, Madrid.

Guitart, Jorge (1982) "On the use of the Spanish subjunctive among Spanish-English bilinguals," Word 33.

Real Academia Española (1973) Esbozo de una nueva gramática de la lengua española, Espasa-Calpe, Madrid.

Terrell, Tracy 他 (1974) "A semantically based analysis of mood in Spanish," Hispania 61.

Togeby, Knud (1953) Mode, aspect et temps en espagnol, Det Kongelige Danske Videnskabernes Selskab, Copenhague.

Woehr, Richard (1975) "Grammar of the factive nominal is Spanish," Language Sciences 36 .

拙稿 (1989) 'Sobre la construcción 'el hecho de que + cláusula' (1), " Linguiistica Hispánica 12, 関西スペイン語学研究会。 拙稿（隼储中）"同 (2) n, Linguística Hispánica 次号。 
Sobre la cláusula regida por el hecho de que

por Noritaka Fukushima

El propósito del ensayo presente es investigar el mecanismo con que se determina la forma modal del verbo regido por la frase señalada en el título. La oposición de "realidad/no realidad," que se dice que corresponde a la de los modos indicativo/subjuntivo, no puede ser un criterio muy eficiente para dicha construcción, ya que abundan casos en que el verbo en subjuntivo representa sucesos reales y no imaginarios. Hay que recurrir a algún otro tipo de explicación para comprender tales empleos.

Hemos identificado once ejemplos de la secuencia "el hecho de que + indicativo," y dieciséis de "el hecho de que + subjuntivo" en nuestro corpus del español contemporáneo. La mayoría de estos datos se abarcan en nuestra hipótesis siguiente, inspirada por las ideas de S. Fernández Ramirez y otros gramáticos: "En la cláusula en cuestión, se usa el subjuntivo si el contenido - sea real o imaginarioes un conocimiento presupuesto entre el enunciante y el receptor, mientras que se prefiere usar el indicativo si dicha cláusula aborda una información principal de la oración. Es decir, hay que ver como dos cosas distintas el afirmar algo y el presuponer algo como hecho real."

Un reducido número de ejemplos va, a simple vista, en contra de nuestra hipótesis, pero en realidad sirve para fortificarla, ya que unas encuestas dirigidas a siete hispanoparlantes han demostrado la poca aceptabilidad de dichos ejemplos. Las encuestas han señalado también que el hecho de que requiere el subjuntivo, si esa cláusula no desempeña el foco informativo. 
Otra conclusión que hemos sacado, a través del análisis de los datos reunidos, es que "el hecho de que + indicativo" suele colocarse detrás de otra(s) cláusula(s), lo cual es lo contrario de lo que ocurre con "el hecho de que + subjuntivo." $\mathrm{Ni}$ que decir tiene que estas tendencias son explicables con la hipótesis planteada. 